\title{
[ The Butler Who Married His Lordship: Feminine Identity in Kazuo Ishiguro's The Remains of the Day ]
}

\section{Silvia Chiarle}

University of Turin,

Turin, Italy

[Abstract] Darlington Hall epitomises a political arena that corresponds to what John Ruskin describes as the male public sphere. The main actors in this sphere are Lord Darlington and Stevens, who both regard their activities as a form of service to humanity. Nevertheless, if we analyse Stevens's behaviour not only in the light of Freud's theories about idealisation and love as explained in Group Psychology and the Analysis of the Ego and On Narcissism: An Introduction, but also through the cultural and custom sources that deal with the condition of menservants and wives in the Victorian age, it would appear that Stevens's social sex role conforms more to Ruskin's concept of the feminine. Stevens and Darlington would form a virtual couple, where the former has the role of the wife and the latter that of the husband.

[Keywords] The Remains of the Day; Kazuo Ishiguro; femininity; masculinity; homosexuality; identification; idealisation; narcissistic love; menservants 


\section{[1] Introduction}

There are several perspectives a story can be told from. Readers of Kazuo Ishiguro's Booker Prize-winning novel The Remains of the Day (1989) may be fascinated by the story of the journey, both physical and mental, taken by the butler of Darlington Hall, Mr Stevens. Alternatively, one may read the plot as an unfulfilled love story. Indeed, the trip to Cornwall is a pretext to visit Miss Kenton, the former housekeeper of Darlington Hall, now living with her husband. In my paper, however, I intend to focus my attention on the peculiar relationship across different levels of a hierarchical order: in this sense, one may approach The Remains of the Day as a narrative of loyalty, that of the butler to his master. Back in the glory days, Lord Darlington, the archetypal English aristocrat, owned Darlington Hall; ostensibly, Stevens's self-abnegation restrained him from accepting Miss Kenton's advances and from taking any rest from his work. Certainly, Stevens's absolute loyalty might be considered as a proof of devotion more complex than that expected from a servant: namely, Stevens's attachment resembles that of a wife to her husband. In order to understand how the relationship between Stevens and Lord Darlington is structured, an analysis of the social dynamics at Darlington Hall is needed.

Two prerogatives dominate life at Darlington Hall: the commitment to the public sphere and the male dominance of it. Lord Darlington believes that an aristocratic sense of honour obliges him to be involved in politics, while Mr Stevens regards his job as a way of "furthering the progress of humanity" (Ishiguro 107, 120). Cynthia Wong highlights this point when she writes: "Both Darlington and Stevens behave in accordance with what they deem to be the proper social ideals of the time. [...] For Darlington, appeasement of German powers might stifle an impending war; for Stevens, good service to Darlington is of utmost importance to ensuring world peace. For both, service to a national cause is the order of the day" (Wong 498). Indeed, Ishiguro himself points out how Stevens endeavours to do something for the common good: "He is driven by this urge to do things perfectly, and not only do things perfectly, but that perfect contribution should be, no matter how small a contribution it is, to improve humanity" (Ishiguro, in Vorda and Herzinger 152). The conduct of politics, moreover, unfolds in accordance with the principle of hierarchy: so long as Lord Darlington hosts the conference and mediates between the participants, he remains in a dominant position; Stevens's task, on the other hand, is that of a subordinate who arranges the guests' stay in such a way as to make them perfectly comfortable and content.

Commitment to the public sphere at Darlington Hall is a purely male activity. Besides Lord Darlington and Stevens, the protagonists of the political events that take place in the manor are men (Ishiguro 78-115, 143-6). Terentowicz-Fotyga explains that "Stevens can be said to have fully interiorized the vision of Darlington Hall as public, masculine space. For him, as for Lord Darlington, the country house does not represent domestic comfort but the centre of power where 'debates are conducted, and crucial decisions arrived at' (115)" (91). The concept of 'domestic comfort' alluded to by Terentowicz-Fotyga is one of intimacy, and is described further in the dichotomy between the public and do- 
mestic spheres as affirmed by John Ruskin in Sesame and Lilies (1865): “The man's power is active, progressive, defensive. [...] his energy for adventure, for war, and for conquest. [...] But the woman's power is [...] for sweet ordering, arrangement, and decision" (Ruskin 44). On the one hand, the public world, ruled by men, stands stormy, loveless and violent; on the other, the intimate, sacred and protective sphere, which revolves around hearth and home, is overseen by women.

The concepts of public and private, masculine and feminine, prove to be particularly useful when applied to an analysis of the unfolding relationship between Stevens and Lord Darlington. Nor should such an analysis, carried out with specific reference to the thought of a Victorian author such as Ruskin, seem incongruous: indeed, some critics view the novel's characters as sharing a Victorian mindset. For example, Susie O’Brien states that The Remains of the Day is "a narrative which is thematically constructed around an opposition between what are commonly regarded as Victorian values-formality, repression, and self-effacement, summed up under the general heading of 'dignity'-and those associated with an idea of 'America' that has expanded, literally into a New Worldfreedom, nature, and individualism" (788). And John Rothfork labels Stevens as "a kind of Victorian samurai" (91). Thus, even though Darlington Hall's golden age is that of the 1920 s and '30s, the values of its inhabitants are still anchored to the previous century.

If we adopt Ruskin's division of male and female spheres in order to understand the human relationships at Darlington Hall, one can only regard Lord Darlington and Stevens as representatives of the public male domain. One might also ask, however, who embodies the private female sphere. This might appear to be something of a problem, for, with the exception of Miss Kenton, a feature of The Remains of the Day is the absence of pivotal female characters. Apart from the energetic housekeeper, women are simply bit players. They are generally maids and are not even worthy of a name. If they are given a name at all, it is a stereotyped one: the Jewish maids are called Ruth and Sarah, and have no psychological depth (Ishiguro 156). Lisa is a butler's prototypical nightmare: a housemaid who leaves her job because she has fallen in love with the second footman (Ishiguro 163-7). The cook at Darlington Hall, Mrs Mortimer, becomes almost the perfect caricature when, in assisting Stevens senior, she fills the whole room with the smell of a roast meat (114). Miss Kenton, on the other hand, though a fully rounded character, is also something of a loose cannon: her forceful personality is in marked contrast with the dignified, restrained comportment of the inhabitants of Darlington Hall and appears somewhat out-of-place. The main characters' female relatives come in for even more off-hand treatment. Stevens never mentions his mother, and his father never speaks of his wife. Lord Darlington replicates the pattern by never mentioning his mother, wife, or mistress, and the reader is left at a loss as to whether he is a bachelor or a widower. Darlington Hall is "a rigidly organized, formalized 'anti-home', intrinsically adverse to family life" (Terentowicz-Fotyga 90) and it "resembles a luxurious monastery in one key aspect: none of its inmates has any kind of sex life. From the master down to the housekeeper, all lead celibate lives, strenuously sublimating their libidinal energies in the performance of their duties" (Tamaya 50). 
The aim of this essay is to establish who actually embodies the domestic, female sphere at Darlington Hall. My purpose is to demonstrate that Stevens's devotion to his job, and to his lord, is only a superficial expression of his involvement in the public world, and that it is Stevens who, above all, represents the feminine principle at Darlington Hall, serving to create that 'domestic comfort' which Terentowicz-Fotyga claims to be absent in the house and, in doing so, epitomising Ruskin's definition of the ideal wife: "She must be [...] instinctively, infallibly wise - wise, not for self-development, but for self-renunciation: wise, not that she may set herself above her husband, but that she may never fail from his side: wise, not with the narrowness of insolent and loveless pride, but with the passionate gentleness of an infinitely variable, because infinitely applicable, modesty of service" (Ruskin 45).

At this point, my argument requires a psychological definition of 'sexuality' and 'gender role'. Milite hypothesises that "The four components of human sexuality are biological sex, gender identity (the psychological sense of being male or female), sexual orientation, and social sex role (adherence to cultural norms for feminine and masculine behavior)" (306). Philip Browning Helsel clarifies the concept of social sex role further by calling it 'gender role': "The concept of gender roles refers not strictly to whether one thinks of oneself as male or female, but the way this conviction is played out in the cultural arena, including 'situational constraints' that can maintain behavior that 'seems fitting' to men and women (Rudacille 2005, 56)" (Browning Helsel 700). If one applies these two definitions to Ishiguro's novel, we see that Stevens's gender role presents aspects that are usually considered closer to a feminine stereotype than to a masculine one.

In order to make my argument clear, I shall first analyse Stevens's character under the microscope of Freudian psychoanalysis, after which I shall consider the nature of a butler's task in the nineteenth century, as it is described in contemporary culture and custom sources.

\section{[2] Psychoanalytic sources}

In her book Femininities, Masculinities, Sexualities - Freud and Beyond (1994), Nancy Chodorow argues that "If one parent can be said to 'create' gender in their children or to help in that creation, it is the father" (86). An analysis of Stevens's relationship with his father would seem to be crucial, therefore, if we are to understand how his social sex role develops.

In Group Psychology and the Analysis of the Ego (1921), Sigmund Freud points out that "Identification is known to psycho-analysis as the earliest expression of an emotional tie with another person. [...] A little boy will exhibit a special interest in his father; he would like to grow like him and be like him, and take his place everywhere. We may say simply that he takes his father as his ideal" (Freud, Group Psychology 60). Moreover, "identification endeavours to mould a person's own ego after the fashion of the one that has been taken as a 'model'" (Freud 63). Identification might well describe the feelings 
Stevens nurtures for his father, since he attempts to model his life on that of his father: he chooses the same career and he works hard to achieve the dignity which, in his eyes, his father did. When Stevens recounts the most significant episodes in his father's professional life, he claims that "my father not only manifests, but comes close to being the personification itself, of what the Hayes Society terms 'dignity in keeping with his position"” (Ishiguro 43). Stevens's admiration shines through his words: his father is the personification of dignity, he is a kind of god of butlers. Stevens's mirroring of his father also extends to the identification of gender: his father's dignity was a model of solemn, committed masculinity.

Stevens's affection for his father is not, however, reciprocated. Stevens senior is a gloomy character, and his coldness is palpable: when Stevens is obliged to tell his father that he will no longer be allowed to wait at table, he looks his son "up and down rather coldly" (Ishiguro 67) and replies "I haven't all morning to listen to you chatter" (68). This may seem to be something of a rebuff not only to his professionalism but to his manliness too. When Stevens senior finally admits being proud of his son (101), it is too late. Never once in his lifetime does he grant his son the least sign of approval. If we assume as valid the Freudian concept of identification as "the earliest expression of an emotional tie with another person" (Freud, Group Psychology 60), we must conclude that Stevens senior's failure to address a single word of praise to his son means that his son's feelings were never reciprocated, and that, therefore, no emotional tie was ever formed between father and son. Consequently, Stevens feels the need for a substitute father figure who will reciprocate his feelings: namely, Lord Darlington. As Peter W. Shaffer rightly points out, Stevens has two fathers: "his natural father, also a butler, and his class 'father' and master, Lord Darlington" (Shaffer, Understanding 64). Shaffer also maintains that Stevens ends up no longer identifying "with his lower-class natural father, who suffers both a literal fall (on Darlington's property) and a figurative one (in vocational status), but with his upper-class 'cultural' father and master, Lord Darlington” (Shaffer, Reading 166). Beneath the surface of his pursuit of professional fulfilment, what Stevens really desires is a father figure who will love him. This need is evident when Stevens describes how a butler is to choose a worthy master: "There must surely come a time when he ceases his searching; a time when he must say to himself: 'This employer embodies all that I find noble and admirable. I will hereafter devote myself to serving him.'” (Ishiguro 210-1). Since the master represents 'all that I find noble and admirable', he is a figure the servant can identify with. More specifically, Stevens's identification with Lord Darlington mirrors Charles Rycroft's definition of projective identification: "Projective identification is the process by which a person imagines himself to be inside some object external to himself. This again is a defence since it creates the illusion of control over the object and enables the subject to deny his powerlessness over it and to gain vicarious satisfaction from its activities" (Rycroft 76). Stevens lives vicariously through Lord Darlington, as "professional prestige lay most significantly in the moral worth of one's employer" (Ishiguro 121). Stevens lives in Lord Darlington's shoes almost literally, since he is "in the possession of a number of splendid suits, kindly passed on to me over the years by Lord Darlington himself" (11); 
his identification becomes even more obvious when he relates his life in Moscombe as if he were a gentleman, not a butler, going so far as to almost assume the identity of Lord Darlington (191-203).

Stevens not only identifies with his master, he idealises him, very much in accordance with Freud's definition of idealisation: "By [idealisation] that object, without any alteration in its nature, is aggrandized and exalted in the subject's mind" (Freud, Narcissism 94). Indeed, Stevens sees his master as one of those "great gentlemen of our times in whose hands civilization had been entrusted” (Ishiguro 122); he exalts Darlington's moral stature and endorses his greatness. If a butler's professional dignity is attained only insofar as he serves a great gentleman, Stevens may consider himself to be a great butler. It would seem there is nothing that can stand in the way of Stevens's identification-idealisation with his master. Yet, some differences between Stevens's and Darlington's 'greatness' do exist: Darlington is an aristocrat, Stevens is not; Darlington exercises real influence over historical events, while Stevens does not. As already mentioned, Stevens makes a clumsy attempt to overcome the gulf that separates them socially when hosted by the Taylors, but the class difference between them is insuperable: they both strive to make an active contribution to the common good, but Darlington's superiority to the butler in the social pyramid is unquestionable.

Yet it is precisely this social gap that enables Stevens to take his loyalty to Darlington to another level and to earn his lordship's affection. Insofar as Stevens looks upon Darlington as a heightened, gentlemanly version of himself, he is the embodiment of Freud's description of narcissistic love whereby the subject loves "what he himself would like to be" (Freud, Narcissism 90). Idealisation and love are connected in Freud's formula, as he says, "what possesses the excellence which the ego lacks for making it an ideal, is loved" (101). And he goes on to add that "The object serves as a substitute for some unattained ego ideal of our own. We love it on account of thse perfections which we have striven to reach for our own ego" (Freud, Group Psychology 74). Stevens loves Darlington narcissistically: he loves his master's moral stature, his dignity, his social status and the power that enables him to take decisions at the very "hub" of the world and thus exercise influence over the world's destiny (Ishiguro 122).

It is when Stevens speaks of Lord Darlington, moreover, that we glimpse the hidden sentiments of love that lie beneath the surface of his loyalty. For example, he tells us that when his lordship felt distressed, he showed his solicitude by "remain[ing] there ready to relieve his discomfort at the first opportunity" (85). And when Stevens recalls his days at Darlington Hall in the 1920s and '30s, Lord Darlington is the only person he describes physically, showing empathy, compassion and a hint of nostalgia: "His frame, always slender, had become alarmingly thin and somewhat misshapen, his hair prematurely white, his face strained and haggard" (207). Stevens's description of his employer is even more passionate when he declares: "Whatever may be said about his lordship these days - and the great majority of it is, as I say, utter nonsense - I can declare that he was a truly good man at heart, a gentleman through and through, and one I am proud to have given my best years of service to" (64). Indeed, it is through love that Stevens suc- 
ceeds in entering into Darlington's affection. In his attempt to obtain paternal recognition, Stevens strove to become his father's peer, his worthy heir and copy. But this strategy failed, since Stevens senior never responded to his son's sentiments. Consequently, to obtain Lord Darlington's esteem, Stevens had to take love to its extreme limits and submit totally to Lord Darlington, body and soul. Freud describes the state of being in love as follows: "The ego becomes more and more unassuming and modest, and the object more and more sublime and precious [...]. [E]verything that the object does and asks for is right and blameless. Conscience has no application to anything that is done for the sake of the object [...] The object has taken the place of the ego ideal" (Freud, Group Psychology 74-5). It is interesting to note how Freud compares love to hypnosis: "From being in love to hypnosis is evidently only a short step. [...] There is the same humble subjection, the same compliance, the same absence of criticism" (77). There is no doubt that Stevens becomes wholly incapable of safeguarding his own interests or of distancing himself critically from his lord's actions, maintaining as he does that "our professional duty is not to our own foibles and sentiments, but to the wishes of our employer" (Ishigurol57): he neither opposes the Jewish maids' dismissal (154-8), nor does he enquire into Darlington's connections with the Nazis (230-6), and he is clearly quite prepared to sacrifice his own personal happiness in order to satisfy his lord's wishes. Nor has Stevens's blindness gone unnoticed by the critics: in his Kazuo Ishiguro and Memory (2014), Yugin Teo notes how, “[Stevens's] admiration and awe for Lord Darlington colours his perception of the work Lord Darlington undertakes during the appeasement of Nazi Germany before the Second World War" (29), while Gurewich observes that Lord Darlington makes Stevens "cross the fine line between the loyalty that is the essence of his professionalism and the blind obedience of "just following orders"” (78).

Two psychoanalytic interpretations of the idea of submission intrinsic to being in love may further explain Stevens's attitude. Roslyn Wallach Bologh, in her book Love or Greatness: Max Weber and Masculine Thinking - A Feminist Inquiry (1990), studies Freud's theories as the product of a patriarchal frame of mind; in particular, she argues that masculinity is based on a renunciation of being loved by a caring father, while femininity, given its passivity, fulfils the need for paternal love. Males forsake this need and sublimate it through work in the public sphere, but there are men who fail to sublimate it and still look for a loving father figure whom they can submit to, thus acquiring the passivity that is considered quintessentially female (Wallach Bologh 2-11). The idea of a society where men submit themselves to other men is corroborated by R.W Connell in her book Gender and Power (1987), where she explains that the concept of masculinity is structured in terms of two opposing domains, the 'hegemonic' and the 'submitted' masculinity, the former dominating the latter culturally, psychologically and socially (Connell 183-6). According to Connell, hegemonic masculinity is heterosexual, while homosexuality would be an example of submitted masculinity. It is not difficult to see how Stevens fits into Wallach Bologh's analysis, for failing to obtain his biological father's affection, he loves and submits to a new father figure, giving up his own will, his moral conscience, and his private feelings in order to achieve this figure's love. Following 
Connell's division, Stevens clearly belongs to the 'submitted' masculinity category, since he is socially, culturally and psychologically inferior to Lord Darlington.

Bearing in mind Freud's, Wallach Bologh's and Connell's studies, we can now draw a first conclusion. I have stated above that Stevens's love corresponds to Freud's description of narcissistic love: Freud also maintains that homosexuals are a category very prone to develop this kind of bond, because they do not take their mothers, but rather themselves, as models for their love-object (Freud, Narcissism 88). Narcissistic love also entails a hypnosis-like docility, which Connell relates to the submitted masculinity associated with a homosexual nature. It is conceivable, therefore, that Stevens's attraction to Darlington betrays not only a need for paternal approval, or awe before a man of power, but a latent homosexual attraction. Moreover, Stevens adopts feminine attitudes in order to obtain Lord Darlington's love, thus changing his social sex role. Returning to Milite's definition of the four components of human sexuality quoted in the introduction, and providing that we accept Bologh's definition of female nature as passive and submissive, one can argue that Stevens's sexual orientation is homosexual, whereas his social sex role, defined as the "adherence to cultural norms for feminine and masculine behavior" (Milite 306), is female.

In order to understand how Stevens gradually assumes a female social sex role, it is of considerable interest to compare culture and custom studies about the butler's job and its social perception with the prototypical wife figure. The studies I have taken into consideration deal solely with the Victorian/Edwardian age, since it is the values and habits of this period that affect the mindset of Darlington Hall's inhabitants.

\section{[3] Culture and custom sources}

The extent to which a butler was expected to be devoted to his master is described by E. S. Turner in What the Butler Saw - Two Hundred and Fifty Years of the Servant Problem (1965): "A butler who married was guilty of selfishness as well as vulgarity. [...] [A] married butler spent too much of his master's time on his own affairs [...]. Thus, the very least that a zealous and right-thinking butler owed his master was a vow of celibacy" (159). This being the case, it is clear that Stevens could in no way accept Miss Kenton's advances for fear of failing in his duties to his lordship and losing his job. However, owing a vow of celibacy to one's master actually means being his faithful mate: just like a nun who takes a vow of chastity becomes Christ's spouse, so a butler who renounces love for the opposite sex becomes by implication his master's partner. If we then combine this duty to be a bachelor with the feminisation associated with domestic jobs, the image of the butler as his master's wife emerges all the more clearly. Lucy Delap, in Knowing Their Place - Domestic Service in Twentieth-Century Britain (2011), explains how menservants were perceived during the Victorian and Edwardian age: "Male servants had a comic value distinctive from that of female servants, and were characterized as funny because of the feminization of twentieth-century domestic service. There was a pervasive sense that the domestic male was faintly ridiculous [...]. In the early twentieth century, it was 
felt that, as The Spectator put it in 1914, 'some very faint aroma of ridicule still clings to... the thought of domestic service, at any rate for men." (Delap 160). Delap goes on to develop this picture of male servants: "Their masculinity was compromised by what one Victorian etiquette manual derided as 'this heaping of gold lace, gaudy colours, blooming plushes on honest John Trot'. Interwar depictions of 'the house-parlour-man' were clearly intended to be belittling. Men in service were effeminized and thus laughable" (161). Both the chastity and loyalty described by Turner and the feminisation analysed by Delap seem to merge together in the characterisation of Stevens. In fact, Stevens himself compares the butler to the lord's wife: "If I may put it this way, sir, it is a little akin to the custom as regards marriages. If a divorced lady were present in the company of her second husband, it is often thought desirable not to allude to the original marriage at all. There is a similar custom as regards our profession, sir" (Ishiguro 131).

Taking together the butlers' celibacy and feminisation on the one hand, and Stevens's comparison of butlers and wives on the other, we can describe how the perfect wife was supposed to behave and, consequently, verify to what extent Stevens corresponds to this model. Another text is particularly helpful in this regard: The Women of England, by Sarah Stickney Ellis (1839), who describes three specific qualities that the perfect English Lady of the house ought to possess. Above all else, she was expected to discharge her duties with "promptitude in action" and "energy of thoughts" (Stickney Ellis 21), meaning that "the machinery of household comfort" would not allow for any sort of delay or laziness (23). In fact, Stevens does everything he can to make life at Darlington Hall run as smoothly as possible for Lord Darlington and his guests. He does not give himself a moment's rest, and all his energy is dedicated to the efficient functioning of the machinery of the house. This is particularly evident when he delivers "a military-style "pep-talk"” to the staff (Ishiguro 81). Stevens's tireless activity is aptly conveyed by Ishiguro: "In the course of clearing the dining room, and also in preparing the drawing room for the arrival of the evening's visitors, I was obliged to walk repeatedly past the smoking-room doors" (227). He is so absorbed by his managerial duties that he feels lost when he finally has to prepare for the motoring trip: "It was an odd feeling and perhaps account for why I delayed my departure so long, wandering around the house many times over, checking one last time that all was in order" (23). His behaviour is that of a Lady of the house who presides over her home, and for whom the only judgement that counts is her own. As Sharon Yang points out in describing the lives of Victorian women, presiding over one's home went hand-in-hand with self-abnegation (Yang 25-6): the perfect Victorian woman always put her family's needs before her own, and this is a very evident trait of Stevens's character. His self-abnegation is nowhere more evident than when he states: "As far as I am concerned, Miss Kenton, my vocation will not be fulfilled until I have done all I can to see his lordship through the great tasks he has set himself. The day his lordship's work is complete, the day he is able to rest on his laurels, content in the knowledge that he has done all anyone could ever reasonably ask of him, only on that day, Miss Kenton, will I be able to call myself, as you put it, a well-contented man" (Ishiguro 182). And it is precisely because of this sense of loyalty that Stevens never left the mansion, concealed his true 
thoughts when the Jewish maids were dismissed (156) and, most importantly, repressed his feelings for Miss Kenton (225-26, 229-30).

The third quality Stickney Ellis highlights is "benevolence of feeling" (21), which may be understood as the care the Lady of the house demonstrates when working to ensure that all family members and guests feel at their ease (23-7). Stevens acts in a very similar manner, especially when he seems to intuit what is going on in his employer's mind. For example, he knows that when Lord Darlington feels embarrassed, uneasy or worried, or when he is obliged to ask the butler to do something uncongenial, he pretends to be reading a book (Ishiguro 63). This ability to gauge Lord Darlington's feelings emerges elsewhere in the text: "It was invariably embarrassment at what he was about to impart which made Lord Darlington adopt such an approach" (63, italics mine), or "Lord Darlington called me into his study, and I could see at once that he was in a state of some agitation. [...] 'Oh Stevens' he began with a false air of nonchalance, but then seemed at a loss how to continue" (84-5, italics mine). It seems that Stevens has a special sensitivity when it comes to his dealings with Lord Darlington, a sensitivity wholly lacking in his relationship with Miss Kenton, a woman he never manages to understand.

It is also true that the attention displayed by Stevens towards his master is partly reciprocated: Lord Darlington is far from unfeeling towards his butler, and expresses concern for his welfare on numerous occasions. For instance, during the closing dinner of the conference, with his father on his deathbed and tense political discussions taking place in the mansion, Stevens has the following exchange with his employer:

I felt something touch my elbow and turned to find Lord Darlington.

'Stevens, are you all right?'

'Yes, sir. Perfectly.'

'You look as though you're crying.'

I laughed and taking out a handkerchief, quickly wiped my face. 'I'm very sorry, sir. The strains of a hard day.'

'Yes, it's been hard work.' (109-10)

In the formal context of Darlington Hall, Lord Darlington's touching of Stevens's elbow reveals the affection he feels for his servant. Even in the middle of a potentially historic event, he finds time to enquire about his butler's well-being. Furthermore, the last sentence suggests a complicity between Lord Darlington and Stevens, both of whom are working hard.

The very structure of their dialogue intimates the strong bond between them. Stevens repeats phrases like 'Yes, sir' or 'Indeed, sir' several times, which might appear to be nothing more than the standard way a perfect butler showed respect for his master. Yet such phrases appear only in exchanges between Stevens and Lord Darlington. In those between Mr Farraday and Stevens, on the contrary, the American continues to talk while the butler remains almost silent, though his unspoken thoughts are conveyed to the reader. If Stevens does speak, it is only as an unsuccessful attempt at banter (15-18). No 'Yes, sir' or 'Indeed, sir' is uttered, and the attempt at communication between the two 
only reveals how very different they are from one another. We therefore cannot always take Stevens's use of such language at face value, for, if analysed from a phatic point of view, we see that it signifies Stevens's desire to reassure Lord Darlington that he is listening, and to establish an affectionate contact with his master. And this he is able to do because Lord Darlington pauses from time to time, thus giving Stevens the opportunity to speak. The dialogic exchanges between Lord Darlington and Stevens reveal the nature of the bond that unites them. When Lord Darlington returns from his trip to Germany in 1920, for example, Stevens realises that his master is upset. He asks how his journey has gone, and Lord Darlington confesses to be disturbed by the situation he found in Germany (74). A similar confession is made when, reading a newspaper, Lord Darlington tells Stevens of his contempt for Frenchmen (79). This type of frank dialogue between employer and employee would have been unusual in the period we are discussing, though it might well have occurred between husband and wife: the husband, after a day of public business and politics, would have been happy to return home and relax; the wife, on the other hand, would have listened to her husband dutifully, and attended to his every need. This was the idyllic Victorian marriage, in which the husband held sway while at the same time nurturing affection for his staunchly loyal wife, whose happiness would have been realised in total devotion to her beloved husband. The hierarchy that prevailed in Victorian marriage provides us with more than a simple analogy with the relationship between master and butler. Both wife and butler are, to quote Coventry Patmore, the Angel in the House, and both are expected to be in love with husband and master respectively, in the way Freud describes as being in love: that is, prioritising the loved one's desires first and exalting him/her, while mortifying one's own ego and denying one's own needs.

All the wife-like attitudes recognisable in Stevens correspond to the feminine qualities that Wallach Bologh and Connell attribute to men who submit to other men. They corroborate, therefore, the feminised nature of Stevens's social sex role. Together with Stevens's latent homosexual feelings for Lord Darlington, they aptly describe a butler who is engaged to his master and who cannot respond in any way to Miss Kenton's romantic proposals. And the episode that definitively seals Stevens's bond with Lord Darlington occurs ons the night his father dies, an episode that may be described as a wedding in the real sense of the word.

\section{[4] Conclusions}

That dramatic night proved to be, as Stevens himself points out, "a turning point" (114), since he found himself forced to choose between his "biological father" and his "class father" (Shaffer Understanding 64). Both were possible models that Stevens could identify with, but he needed something more than a model: what he needed above all was a love-object for his Freudian narcissistic love, someone who would return his affection, since only in that way could his life of service be felt to be worthwhile.

Even if Stevens senior finally managed to voice his feelings for his son on his deathbed (101), Stevens felt unable either to care for him or to close his eyes, because he had 
already found a new model, or rather, a love-object, in Darlington. To have given his attention to a dying man then would simply have been a waste of time. Though forsaking his father had been painful, as his tears demonstrate (110), Stevens felt a greater need to show his devotion to Darlington and to seal his love for him. Lord Darlington could not be left in any doubt that Stevens was his infallible right-hand man, his working spouse. As a bride herself would do, he had cast off his father's tutorship in order to marry, and become subject to, his master-husband and pass under his control. As Braunstein and Folbre point out, in patriarchal societies - and Darlington Hall is unquestionably a patriarchy, with its male-dominated hierarchy - a woman's submission to her spouse in marriage was attested to by the formula "to honor and obey" (Braunstein and Folbre 25): what Stevens did that night, by disclaiming the filial bond that tied him to his father, was to give Lord Darlington proof that he honoured and obeyed him. It is interesting to note that Stevens himself describes the incident as "the moment in my career when I truly came of age as a butler" (Ishiguro 73, italics mine). The phrase 'coming of age' is used to express the attainment of full development and a readiness to assume adult responsibilities. Such a moment is often marked by a rite of passage. From an anthropological point of view, when a boy comes of age, he is ready to enter the adult world of men and to become himself a breadwinner. A girl's coming of age, on the other hand, usually leads her to marriage. For Stevens, that crucial night constituted a rite of passage, a watershed: it marked the moment when he left his father to choose Lord Darlington as his new model and protector, just as a girl of marriageable age would do in choosing a husband. In uttering the phrase 'coming of age' Stevens is not only referring to the highest point reached in his profession, but also to a shift in his choice of love-object. On the shift being finally achieved, Stevens was overcome by "a large sense of triumph" (115, italics mine): he felt triumphant because he had passed through his rite of passage as a butler, which consisted in binding himself to his lord forever. From then on, Lord Darlington was not just a father figure; he became Stevens's ideal husband in all reality.

Returning to Ruskin's idea of the wisdom of the perfect wife (Ruskin 45), we may ask whether Stevens possessed it. Insofar as it implies self-renunciation, loyalty, and service, I believe such values to be the very foundation of Stevens's view of life. In writing of the peace of the home, moreover, Ruskin issues some stark warnings as to the dangers that might destroy it:

This is the true nature of home-it is the place of Peace; the shelter, not only from all injury, but from all terror, doubt, and division. In so far as it is not this, it is not home; so far as the anxieties of the outer life penetrate into it, and the inconsistently-minded, unknown, unloved, or hostile society of the outer world is allowed by either husband or wife to cross the threshold, it ceases to be home; it is then only a part of that outer world which you have roofed over, and lighted fire in. (44)

Darlington Hall does not conform to such a peaceful pattern of life and cannot be called a home: the international conference represents the "hostile society of the outer world" (44) invading the mansion and sweeping away that private sphere of family 
life without which a house is no longer a home. Stevens's identification with a female gender role, and with a wife-like identity in particular, may be seen as an attempt to recompose a microcosm of affection, an effort to retain some semblance of a private sphere within the public arena that Darlington Hall had become. From this point of view, Stevens's commitment to social affairs is not what Ruskin labels as male, but it corresponds more to what he defines as feminine, since it resembles more the silent, though strong support a Victorian wife was expected to give her husband.

\section{[Bibliography]}

Braunstein, Elissa, Nancy Folbre. “To Honor and Obey: Efficiency, Inequality and Patriarchal Property Rights.” Feminist Economics 7.1 (2001): 25-44.

Browning Helsel, Philip. “Gender roles.” Encyclopedia of Psychology and Religion. Ed. David Leeming. New York: Springer Reference, 2014. 700-702.

Chodorow, Nancy J. Femininities, Masculinities, Sexualities - Freud and Beyond. Lexington: University Press of Kentucky, 1994.

Connell, R. W. Gender and Power - Society, the Person and Sexual Politics. Cambridge: Polity Press, 1987.

Delap, Lucy. Knowing Their Place - Domestic Service in Twentieth-Century Britain. Oxford: Oxford University Press, 2011.

Freud, Sigmund. On Narcissism: An Introduction. 1914. London: Karnac Books, 2012.

---. Group Psychology and the Analysis of the Ego. 1921. London: Hogarth Press, 1949.

Gurewich, David. “Upstairs, Downstairs.” The New Criterion 8.4 (1989): 77-80.

Ishiguro, Kazuo. The Remains of the Day. 1989. London: Faber and Faber, 1999.

Milite, George A. "Homosexuality.” The Gale Encyclopedia of Psychology. Ed. Bonnie Strickland. Detroit: Gale Group, 2001. 306-307.

O’Brien, Susie. "Serving a New World Order: Postcolonial Politics in Kazuo Ishiguro's The Remains of the Day.” Modern Fiction Studies 42.4 (1996): 787-806.

Patmore, Coventry. The Angel in the House. London: Cassell \& Company, 1891. Web. 5 April 2020. https://www.gutenberg.org/files/4099/4099-h/4099-h.htm

Rothfork, John. “Zen Comedy in Postcolonial Literature: Kazuo Ishiguro's The Remains of the Day." Mosaic: An Interdisciplinary Critical Journal 29.1 (1996): 79-102.

Ruskin, John. Sesame and Lilies. New York: John Wiley \& Sons, 1865. Web. 5 April 2020. https://www.gutenberg.org/files/1293/1293-h/1293-h.htm

Rycroft, Charles. A Critical Dictionary of Psychoanalysis. 1968. London: Penguin Books, 1972.

Shaffer, Brian W. Reading the Novel in English 1950-2000. Malden: Blackwell Publishing, 2006.

---. Understanding Kazuo Ishiguro. Columbia: University of South Carolina Press, 1998.

Stickney Ellis, Sarah. The Women of England: Their Social Duties and Domestic Habits. Philadelphia: E.L. Carey and A. Hart, 1839. 
Tamaya, Meera. “Ishiguro’s ‘Remains of the Day’: The Empire Strikes Back.” Modern Language Studies 22.2 (1992): 45-56.

Teo, Yugin. Kazuo Ishiguro and Memory. Basingstoke: Palgrave Macmillan, 2014.

Terentowicz-Fotyga, Urszula. Dreams, Nightmares and Empty Signifiers - The English Country House in the Contemporary Novel. Frankfurt am Main: Peter Lang Edition, 2015.

Turner, Ernest Sackville. What the Butler Saw: Two Hundred and Fifty Years of the Servant Problem. 1962. London: Penguin Books, 2001.

Vorda, Allan, Kim Herzinger. “An Interview with Kazuo Ishiguro.” Mississippi Review 20.1/2 (1991): 131-54.

Wallach Bologh, Roslyn. Love or Greatness: Max Weber and Masculine Thinking - A Feminist Enquiry. London: Routledge Revivals, 1990.

Wong, Cynthia. "Kazuo Ishiguro's The Remains of the Day." A Companion to the British and Irish Novel, 1945-2000. Ed. Brian W. Shaffer. Malden: Blackwell Publishing, 2005. 493-503.

Yang, Sharon. "Victorian Refashioning: Rosalind as a Paragon of Victorian Womanhood.” Text and Performance Quarterly 22.1 (2002): 24-46.

\section{[Acknowledgements]}

I wish to thank professor Pier Paolo Piciucco (University of Turin) for giving me advice and support in this research.

\section{[Address]}

Department of Foreign Languages and Literatures and Modern Cultures

University of Turin

Via Verdi 8

10124 - Turin

Italy

silvia.chiarle@edu.unito.it

After graduating in Modern Languages and Literatures at the University of Turin, Department of Foreign Languages and Literatures and Modern Cultures, Silvia Chiarle was chosen to take part in a program of research on contemporary English Literature. This essay is a further elaboration of her final dissertation, "Hybridity and Ambiguity in Kazuo Ishiguro's The Remains of the Day. An analysis of Mr Stevens's Conflicting Dichotomies of the Samurai vs the Butler and Masculinity vs Femininity." 